\title{
The Bio-methane Potential of the Water Hyacinth (Eichhorniacrassipes)
}

\section{Clairmont L. Clementson ${ }^{1 *}$, Darren Wilson ${ }^{2}$ and Paulette Ragobeer ${ }^{3}$}

\author{
${ }^{1}$ Research Scientist, National Agricultural Research and Extension Institute, Mon Repos, East \\ Coast Demerara, Guyana. \\ ${ }^{2}$ Research Assistant, University of Guyana, Turkeyen, East Coast Demerara, Guyana. \\ ${ }^{3}$ Lecturer, University of Guyana, Turkeyen, East Coast Demerara, Guyana. \\ Emails: 2darren_24wilson @yahoo .com, 33paulette.ragobeer @uog .edu .gy
}

Article No.: 031216057

DOI: 10.15580/GJAS.2016.5.031216057

Submitted: 12/03/2016

Accepted: 16/03/2016

Published: 30/05/2016

${ }^{*}$ Corresponding Author

Clairmont L. Clementson

E-mail:kemba_cc@yahoo.com

\section{Keywords:}

water hyacinth, waste

management, waterways

maintenance, anaerobic digestion
The maintenance of waterways by local municipalities and irrigation authority has been made difficult due to the presences and nature of Eichhorniacrassipes, commonly known as water hyacinth. The water hyacinth is a very aggressive invader that forms copious mats, covering the entire surface of waterways. It causes oxygen depletion resulting fish kill. This plant species has no known direct food value to wildlife and is considered a pest species. In its drive for green economic development, its potential energy contribution within a slurry mixture via biomethanization should be explored. Biomethanization has become an increasing interest in many industrialized societies for the socio-economic benefits of being able to utilize organic waste to produce an environmentally friendly biogas which reduces carbon emissions to the environment burned. Also, the effluent can be used as fertilizers and raw materials for composting. Utilization of water hyacinth in this manner will certainly aid in the reduction of pollution in local waterways hence this study seeks to compare the anaerobic digestion of manure and water hyacinth, and determine the water hyacinth-manure mix ratio for optimum gas production.

In this research, fresh water hyacinth was collected and chopped up into small pieces. A series of experiments using the biodigesters was conducted, where each biodigester was fed with chopped water hyacinth and mixed with various combinations of manure $(100 \%$, $75 \%, 50 \%, 25 \%$ and $0 \%$ ) and $250 \mathrm{ml}$ of water, for five different fermentation slurries. Biomethanation was carried out in triplicates with a retention time six (6) weeks (42 days) in the mesophilic temperature range. The study showed that there was no statistical difference in the methanization of manure and water hyacinth. Further, the $25 \%$ water hyacinth and $75 \%$ manure $(25 \% \mathrm{~W} . \mathrm{H}-75 \% \mathrm{M}) \mathrm{mix}$ ratio produced the highest volumes of biogas that was significantly different from all other slurry mixtures. This implies that water hyacinth can be used to enhance biogas production. 


\section{INTRODUCTION}

Eichhorniacrassipes, commonly known as water hyacinth, is a free-floating perennial plant that can grow to a height of 3 feet. The dark green leaf blades are circular to elliptical in shape and are attached to spongy, inflated petioles and underneath the water, it has a thick, heavily branched, dark fibrous root system. This plant has demonstrated that it is excellent in water depollution for domestic water wastes. Water hyacinth has the ability to remove $65 \%$ of lead, $50 \%$ of cadmium, and $65 \%$ of mercury from water polluted with $10 \mathrm{ppm}$ of lead and 1 ppm of mercury and cadmium Lareo and Bressani. However, Eichhorniacrassipes is an extremely fast growing plant species that can double its population within 6 to 18 days. The leaves of $E$. crassipes show functional characteristics of C3 plants, but the photosynthetic process indicates some features of the more productive C4 plants. This makes the plant highly efficient in relative growth rates and studies suggest it has the capability to increase its biomass by up to $12 \%$ per day $(\mathrm{CABI}, 2014)$. The water hyacinth is a very aggressive invader that forms a copious mat, covering the entire surface of waterways and causing oxygen depletion and fish kill. This plant species has no known direct food value to wildlife and is considered a pest species (Tamu, 2014). Water hyacinths should therefore be controlled so that they do not clog an entire drainage system.

Water hyacinth has been a challenge to the Georgetown city council and the National Drainage and Irrigation Authority in the maintenance of canals and drains in Guyana. Control studies of the hyacinth used several kinds of animals, viruses, bacteria and fungi. However, results were poor, perhaps because of the defense mechanism in the plants that form more leaves for every one destroyed by pathogen attack. Locally, Haigh (1991) used the West Indian manatee, Trichechusmanatus, an herbivorous mammal that feeds on aquatic plants to collect data from a number of sites to establish the reliability of the manatees as a weed control agent. The aquatic mammals appeared to have considerable advantages over the other methods of weed control and therefore, the study supported the reason that manatees can be a practical alternative for weed infestation in irrigation and drainage in Guyana and other tropical countries. Another study, aimed at large scale processing of organic waste (grass, water hyacinth, water hyacinth + grass) in three different combinations through bio-dung and vermicomposting. The results indicated that the pre-digestion of organic waste through anaerobic and aerobic decomposition was most effective and revealed that the water hyacinth and grass can be efficiently utilized by earthworms to produce vermicompost. Thus, it was recognized that the use of water hyacinth and grass produced very nutritious biofertilizers and the quantity of nutrients had an ideal level that would promote plant growth. The author concluded that this technology can be successfully implemented in Guyana for organic solid waste management (Ansari and Rajpersaud, 2012).

The water hyacinth has been found to use considerable amounts of the inorganic forms of nitrogen and phosphorus found in domestic sewage. Basically, the effect is a significant reduction in the concentration of materials that are major contributors to the inorganic nutrient enrichment of natural waters. Because inorganic nitrogen and phosphorus are accumulated largely in the roots, this signifies further, another possible use for the water hyacinth as compost or organic fertilizer. However, the plant's fibers are not degraded and the fibrous component might be useful as a base for a biogasproducing system since methanogens require nutrients as nitrogen, potassium, and phosphorus. Studies have shown that water hyacinth provides these elements in the quantity adequate for good growth of bacteria and satisfactory gas production Lareo and Bressani.

Another waste management system can be implemented here in Guyana is through the removal and management of the water clogging plant, the water hyacinth through anaerobic digestion. Anaerobic digestion is the method of waste treatment intended to reduce the hazardous effects of organic pollution on the environment. The mutualistic behavior of the various anaerobic microorganisms results in the decomposition of complex organic substances into simple, chemically stabled compounds, mainly methane and carbon dioxide $\left(\mathrm{CO}_{2}\right)$.

This study seeks to add more information that would support the use of the water hyacinth as digestible material in anaerobic digesters and to weigh the ecological and economic benefit of producing biogas from a water hyacinth co-digester for Guyana.

\section{RESEARCH OBJECTIVES}

The general objective is to establish anaerobic digestion as a possible method for water hyacinth management in Guyana. The specific objectives are:

1. Compare the anaerobic digestion of cow manure and water hyacinth obtained locally.

2. Determine the water hyacinth-manure mix ratio that produces optimum volume of biogas.

3. Ascertain the influence of volatile and total solids percentage on the biogas production.

\section{RESEARCH METHODOLOGY}

Six (6) digesters were made by placing 2" (inches) diameter PVC pipes of length 3' 10" (three feet ten inches) inside 4" diameter PVC pipes of length 4' (four feet) and sealing one end with plexiglass to form the base of the digester. The digestible material (slurry) was 
placed in the 2" pipes. Water was poured into the 4" pipes in the space surrounding the 2" pipe to a height of 3' 8" (three feet eight inches). A cap was placed on a 3" (three inches) diameter PVC pipe and length 3' (three feet), this was placed over the 2" pipe to eliminate the entry of oxygen to the slurry and create a pressure system to trap the biogas.

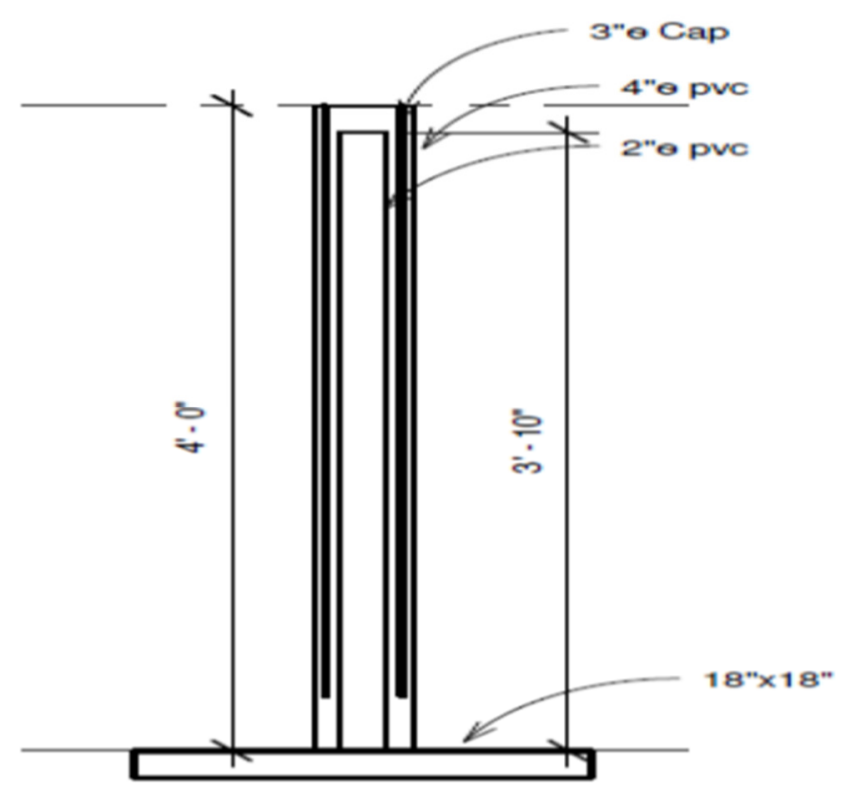

Figure 1: Shows the design of the digesters

Fresh water hyacinth (Eichhorniacrassipes) was collected from a local waterway close to the University of Guyana (Turkeyen, Georgetown) and chopped up into small pieces. Bovine manure was collected from a farm within the same proximity. The chopped water hyacinth was mixed with manure and $250 \mathrm{ml}$ of water to create five different fermentation slurries with water hyacinth content of $0 \%, 25 \%, 50 \%, 75 \%$ and $100 \%$ respectively. The slurries were the transferred to the digesters in triplicate for biomethanation with a retention time six (6) weeks (42 days) in the mesophilic temperature range. Accumulative biogas production were monitored twice weekly throughout the period of the study by measuring the height of the gas chamber.

Water hyacinth samples were crushed and $50 \mathrm{~g}$ was placed evenly on the evaporating dish. Also, samples representing $75 \%, 50 \%$ and $25 \%$ of $50 \mathrm{~g}$ were weighed and combined with manure at $25 \%, 50 \%$ and $75 \%$ respectively to make up the total $50 \mathrm{~g}$ weight. The samples were dried at $103-105^{\circ} \mathrm{C}$ for $12 \mathrm{hrs}$, cooled in a desiccator to stabilize the samples. The residues were then reheated for $1 \mathrm{hr}$ and weighed again. This was repeated until constant weight was achieved. The final weight was recorded as ' $A$ '. An empty evaporating dish was weighed and recorded as 'B'. Total solids were calculated using the following formulae:

$$
\% \text { Total solids }=\frac{A-B}{50-B} * 100(\text { US. EPA, 2001) }
$$

The evaporating dishes that contained the dried residues were then transferred to a cool furnace. The furnace was heated to $550^{\circ} \mathrm{C}$ and ignited for $2 \mathrm{hrs}$ and thereafter, the residues were placed in a desiccator to stabilize the samples. The residues were then weighed and once again, ignited for 30 minutes. A series of ignition, cooling and weighing continued until weight changes were minimal. The final weight was recorded as ' $C$ '. Volatile solids were calculated using the following formulae:

$$
\% \text { Volatile solids }=\frac{A-C}{A-B}{ }^{\star} 100(\text { US. EPA, 2001) }
$$

Data collected were tabulated, charted and presented in graphical form. Regression analysis and ANOVA was used to establish whether there are relationships between the amounts of plant material used vs. the amount of animal material and their statistical significance.

\section{RESULTS}

This research sought to observe, compare and document from an experimental point of view the anaerobic digestion of cow manure and water hyacinth obtained locally. The cow manure produced slightly more gas than the water hyacinth; however there was no statistical difference in their gas production (table 1). 
It is seen that as the manure component of the mix increased and the water hyacinth component of the ratio decreased there was an increase in the average volumes of biogas produced. Themix ratio of recorded the highest average biogas production with $6.59 \mathrm{~L}$, followed by $50 \% \mathrm{~W} . \mathrm{H}-50 \% \mathrm{M}$ at $5.25 \mathrm{~L}$ and the $75 \% \mathrm{~W} . \mathrm{H}-$
$25 \% \mathrm{M}$ ratio evolved the least average volume of biogas at $2.40 \mathrm{~L}$. There was statistical difference in the biogas produced from the mix ratios (table 1). Therefore the $25 \% \mathrm{~W} . \mathrm{H}-75 \% \mathrm{M}$ mix ratio produced the optimum volume of biogas.

Table 1: Showing the average gas evolved from the various slurry mixtures and the significant differences

\begin{tabular}{|l|l|l|}
\hline Slurry & Average gas evolved $(\mathrm{L})^{\S}$ & Standard deviation \\
\hline $100 \% \mathrm{WH}-0 \% \mathrm{M}$ & $1.91^{\mathrm{a}}$ & 1.86 \\
\hline $75 \% \mathrm{WH}-25 \% \mathrm{M}$ & $2.40^{\mathrm{a}}$ & 1.92 \\
\hline $50 \% \mathrm{WH}-50 \% \mathrm{M}$ & $5.25^{\mathrm{b}}$ & 1.97 \\
\hline $25 \% \mathrm{WH}-75 \% \mathrm{M}$ & $6.29^{\mathrm{c}}$ & 3.60 \\
\hline $0 \% \mathrm{WH}-100 \% \mathrm{M}$ & $2.52^{\mathrm{a}}$ & 2.62 \\
\hline
\end{tabular}

${ }^{\S}$ significant difference of mean

WH - Water Hyacinth

$\mathrm{M}$ - Manure

Table 1 shows a summary of ANOVA analysis which compares the anaerobic digestion of cow manure and water hyacinth. It gives data that states whether there are significant differences or not in the variances compared. Comparisons between variances are only deemed statistically significant when the $P$ value is $<0.05$ and is $F$ value is greater than the $F$ critical value.

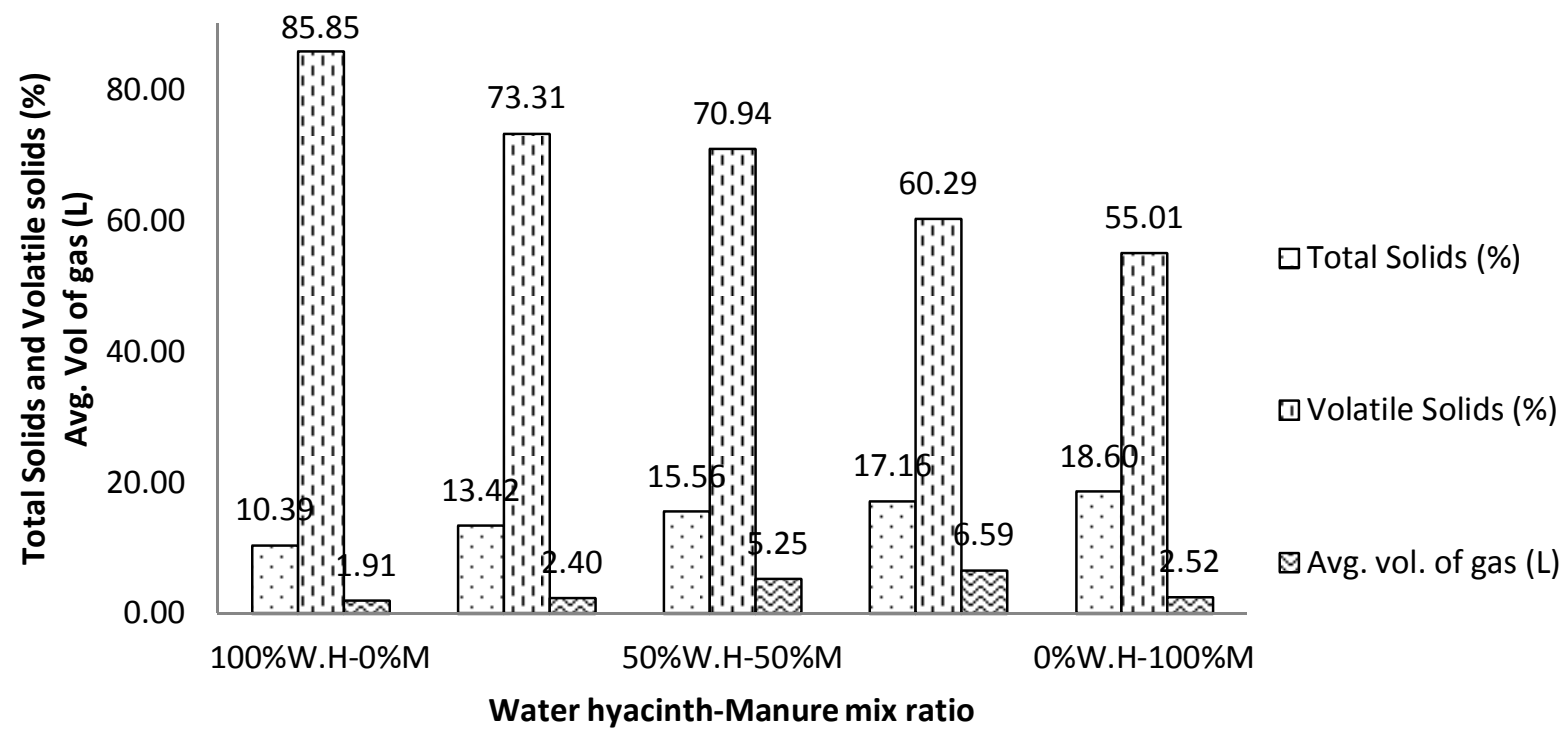

Figure 2: Showing a comparison between total solids, volatile solids and biogas evolved by the various slurry mixtures

The general relationship seen in figure 2 points out that as the water hyacinth component of the mix decreased, Total solids percentage increased. This trend showed up again in relation to the average volume of biogas produced. Volatile solids had a decreasing trend as the water hyacinth component decreased from $100 \%-0 \%$. In the Figures 3-5 below, the relationship between total solids, volatile solids and average biogas evolved are correlated and graphed on scatter charts. In Figure 3, it shows that there was a negative relationship between Volatile solids (VS) and Total solids (TS) with an R square value of 0.9664 , a positive relationship between average biogas produced and total solids with an $R$ square value of 0.2442 (Figure 4) and a negative relationship between average biogas evolved and 
volatile solids with an $\mathrm{R}$ square value of 0.1742 (Figure

$5)$.

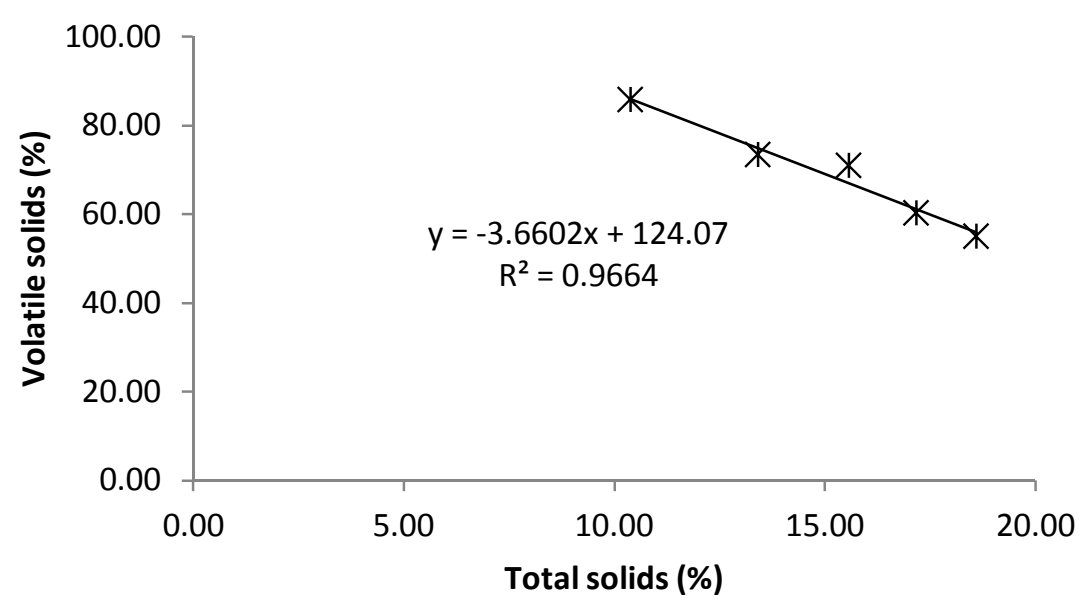

Figure 3: Showing the regressive relationship between Total Solids (TS) and Volatile solids (VS)

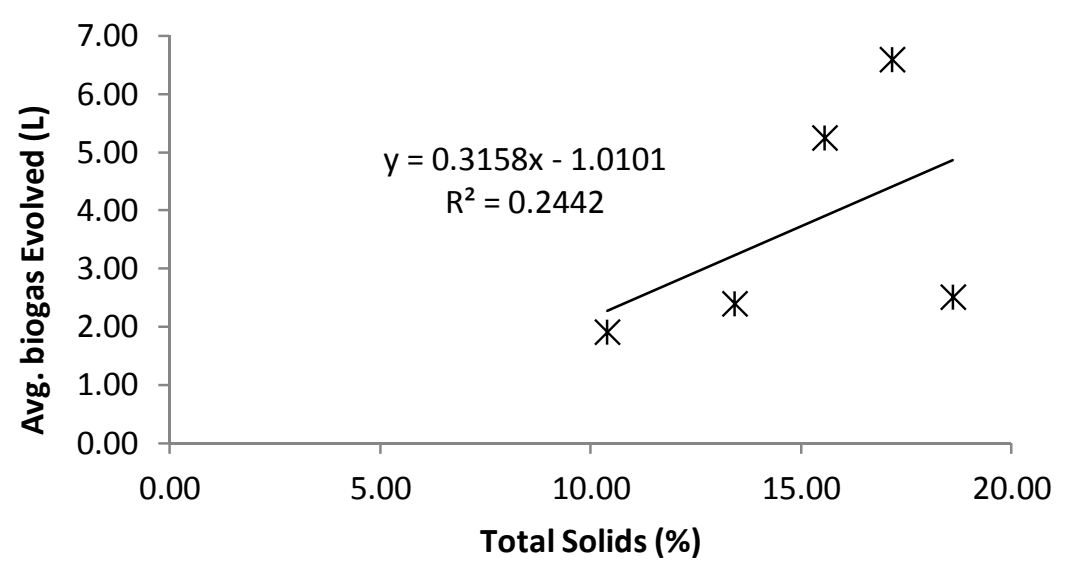

Figure 4: Showing the regressive relationship between Total Solids (TS) and average gas evolved

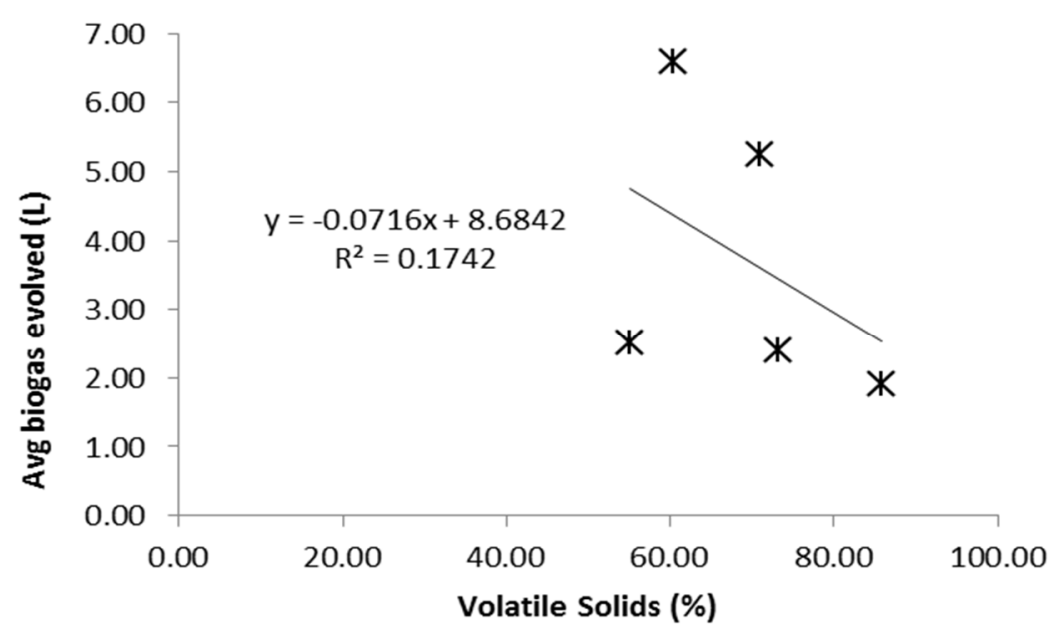

Figure 5: Showing the regressive relationship between Volatile Solids (TS) and average biogas evolved 


\section{CONCLUSION}

This study seeks to compare the anaerobic digestion of manure and water hyacinth, and determine the water hyacinth-manure mix ratio for optimum gas production. The study showed that water hyacinth and manure codigesters produced higher volumes of biogas than that which contained water hyacinth or manure only. This indicate that the manure acted as an inoculum of bacteria and that the concentration of bacteria present in the manure worked superbly to decompose the highly organic digestible material and thus, the addition of manure to water hyacinth resulted in an increased biogas evolution. The $25 \%$ water hyacinth and $75 \%$ manure $(25 \% \mathrm{~W} . \mathrm{H}-75 \% \mathrm{M})$ mix ratio produced the highest volumes of biogas that was significantly different from all other slurry mixtures; hence this mix ratio should be used for optimum gas production. Further it was shown that total solids and volatile solids had a positive and negative relationship respectively to the average biogas evolved. This study indicates that this problematic material could be utilized for economic and environmental benefits.

\section{ACKNOLEDGEMENT}

The authors would like to thank the University of Guyana, Turkeyen, and the National Agricultural Research and Extension Institute, Mon Repos, East
Coast Demerara, Guyana for their contribution towards this study and its publication.

\section{REFERENCE}

Ansari, A. A., and Rajpersaud, J. (2012).Physicochemical Changes during Vermicomposting of Water Hyacinth (Eichhorniacrassipes) and Grass Clippings.Soil Science, 2012, 1-6.

Haigh, M. (1991). The use of manatees for the control of aquatic weeds in Guyana. Irrigation and drainage systems 5(4):339-349.

Lareo, L., and Bressani R. (1982).Possible utilization of the water hyacinth in nutrition and industry. Food and Nutrition Bulletin 4(4):10.

Tamu.edu. (2014). Water Hyacinth, Eichhorniacrassipes. Retrieved 12/17/2014. http://aquaplant.tamu.edu/plantidentification/alphabetical-index/water-hyacinth/.

U.S. Environmental Protection Agency Office of Water Office of Science and Technology Engineering and Analysis Division (U.S. EPA).(2001). METHOD 1684 Total, Fixed, and Volatile Solids in Water, Solids, and Biosolids.

Center for Agricultural Bioscience International (CABI). 2014. Eichhorniacrassipes. Retrieved 12/20/2014. http://www.cabi.org/isc/datasheet/20544.

Cite this Article: Clairmont LC, Darren W and Paulette R (2016). The Bio-methane Potential of the Water Hyacinth
(Eichhorniacrassipes). G Greener Journal of $\quad$ Agricultural
http://doi.org/10.15580/GJAS.2016.5.031216057.

